原

肺癌手術症例に括ける分化度と予後

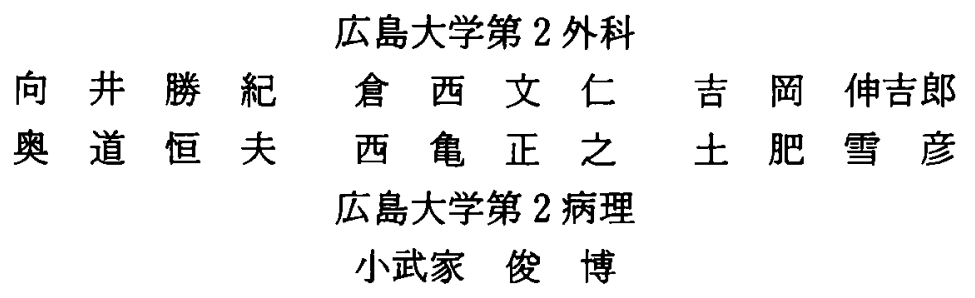

1972年から1987年まで16年間における肺癌切除症例274例中, 扁平上皮癌123例, 腺癌 127例を分化度別に分類し予後を検討した。

扁平上皮癌の 5 年生存率は高分化型 $44 \%$ ，中分化型 $38 \%$ ，低分化型 $43 \%$ で，分化度間 の予後の差は殆ど認めなかった.一方, 腺癌の 5 年生存率は高分化型 $53 \%$, 中分化型 $42 \%$, 低分化型 $0 \%$ で，分化度が低い程予後の悪い傾向を認めた．腺癌の胞巣形態別の 5 年生 存率は alveolar cell type が60\%と良好であったが, tubular type は22\%で不良であっ た.

扁平上皮癌では分化度の高いもの汪肺門側に発生する傾向があったが，各分化度間 で根治度, 進行度, 生存率等に殆ど差は無く, 分化度と生存率に一定の関連は認められ なかった. 腺癌では分化度が高くなるほど末梢型の割合が増卉， $\mathrm{T}$ 因子や $\mathrm{N}$ 因子も低く stage の早い症例が多く，絶対治癁切除の割合も高く，これらが予後の良好な要因と考古 られた.

索引用語：肺癌, 肺癌の分化度, 肺癌の予後

\section{はじめに}

原発性肺癌は近年增加の一途をたどっており, 胃癌 を追い越す勢いであるか，その 5 年生存率は今なお 10\%程度と予後不良である. 唯一の根治療法は手術で あるが，その予後は組織型，TNM 因子に上る病期分 類，手術の根治度などによって大きく左右される。乙 かし，手術症例の予後が予想に反する症例も臨床上し ばしば遭遇する．即ち，組織型や病期分類が同一でも 長期生存する症例もあれば，逆に早期に再発する症例 もある. 今回われわれは術後の生存率に影響すると考 えられる因子のひとつである分化度について検討した ので文献的考察を加光報告する。

\section{症例}

1972年から1987年むでの16年間にわれわれの教室で 手術を行った肺癌症例は306例である.そのらち試験開 胸の32例を除いた肺腫場切除274例の組織型, 性別を表 1 K示した。扁平上皮癌123例 (45\%), 腺癌127例

1990 年 8 月23日受付 1991 年 6 月 6 日採用
表 1 肺腫硕切除症例

\begin{tabular}{|c|c|c|}
\hline & & $(1972-1987)$ \\
\hline 扁平上皮癌 & 123例 & 45\%（男115：女 8） \\
\hline 腺癌 & 127例 & 46\%（男 $70 ： 女 57 ）$ \\
\hline 大細胞癌 & 6例 & 2\%(男 4:女 2) \\
\hline 小細胞癌 & 10例 & $4 \%$ （男 $10 ：$ 女 0 ） \\
\hline その 他 & 8例 & 3\%（男 4：女 4） \\
\hline 合 計 & 274例 & 100\%（男203：女71） \\
\hline
\end{tabular}

(46\%), 大細胞癌 6 例 ( $2 \%)$, 小細胞癌10例 ( $4 \%)$, その他 8 例 ( $3 \%$ )で, 扁平上皮癌と腺癌はほぼ同数 であるが，女性では扁平上皮癌が少なく腺癌が多い傾 向にあった。これらの症例のらち病理組織学的に分化 度の判定が可能であった扁平上皮癌113例, 腺癌117例 について検討した，大細胞および小細胞癌や腺扁平上 皮癌は症例数が少なく，今回の検討の対象から除外し た. 分化度および腺癌の胞巣の形態による分類は日本 肺癌学会の取扱い規約1)に従った。すなわち, 多様な分 化度を示している場合は大勢を占める分化の程度を もってその症例の分化度とし, 胞巣形態による分類に 
表 2 扁平上皮㿉と腺凐の各分化度の割合

\begin{tabular}{c|c|c|c|c}
\hline & \multicolumn{2}{|c|}{ 扁平上皮癌 } & \multicolumn{2}{c}{ 腺 } \\
\hline 高分化型 & 32 & $28 \%$ & 46 & $39 \%$ \\
中分化型 & 55 & $49 \%$ & 58 & $50 \%$ \\
低分化型 & 26 & $23 \%$ & 13 & $11 \%$ \\
\hline 合 計 & 113 例 & $100 \%$ & 117 例 & $100 \%$ \\
\hline
\end{tabular}

表 3 平均年龄と分化度

\begin{tabular}{c|c|c}
\hline & 扁平上皮癌 & 腺 \\
\hline 高分化型 & $61.3 \pm 8.3(\mathrm{r}=32)$ & $61.1 \pm 9.7(\mathrm{n}=46)$ \\
中分化型 & $62.0 \pm 8.5(\mathrm{n}=55)$ & $61.3 \pm 8.3(\mathrm{n}=58)$ \\
低分化型 & $62.4 \pm 6.9(\mathrm{n}=26)$ & $57.2 \pm 9.3(\mathrm{n}=13)$ \\
\hline 平 均 & $61.9 \pm 8.1(\mathrm{n}=113)$ & $60.9 \pm 9.2(\mathrm{n}=117)$ \\
\hline
\end{tabular}

表 4 腺富の組阵要型と分化度の煳係

\begin{tabular}{c|c|c|c|c}
\hline & 高分化型 & 中分化型 & 低分化型 & 合計 \\
\hline Alveolar cell type & 15 & 5 & 0 & 20 例 \\
Papillary type & 26 & 30 & 0 & 56 例 \\
Tubular type & 4 & 21 & 8 & 33 例 \\
\hline 合 計 & 45 例 & 56 例 & 8 例 & 109 例 \\
\hline
\end{tabular}

ついても同様に判定した， alveolar cell carcinoma は 標本の大部分を占めるものとし，部分的なるのは papillary type に含めた。いずれる判定困難な例は除 外した。生存率は Kaplan-Meier 法で計算し, 有意差検 定は Generalized Wilcoxon 法にて行った。

\section{結果}

（1）各分化度の割合（表 2）

扁平上皮癌の中分化型が55例 $49 \%$ ，腺癌のそれも58 例 $50 \%$ で，ともに中分化型が約半数を占めている. 低 分化型腺癌は 13 例, $11 \%$ と最も少なかった。

（2）平均年䀫と分化度（表 3）

低分化型腺癌の平均年龄が少し低かった他は扁平上 皮癌, 腺癌とも分化度と年龄との間に大きな差は認め られなかった。

\section{（3）腺瘦の組織型要型分類（表 4)}

腺癌117例中, 病理組織学的に胞巣形態の分類の可能 であったのは papillary type が56例, papillary type の一型である alveolar cell type 20例, tubular type 33例の計109例で，残り 8 例は分類が困難であった。 alveolar cell type は75\%が高分化型で占められ，残り す全て中分化型であった。 papillary type は高分化型

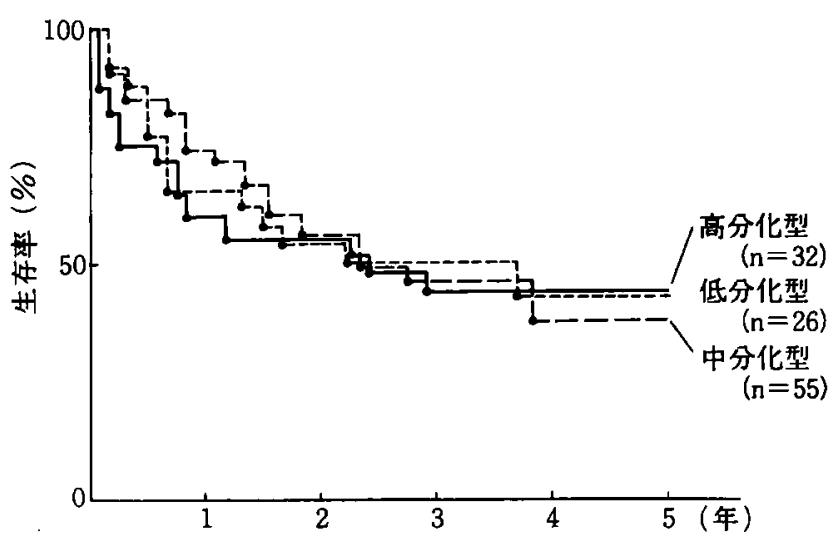

図 1 扁平上皮密の生存曲線

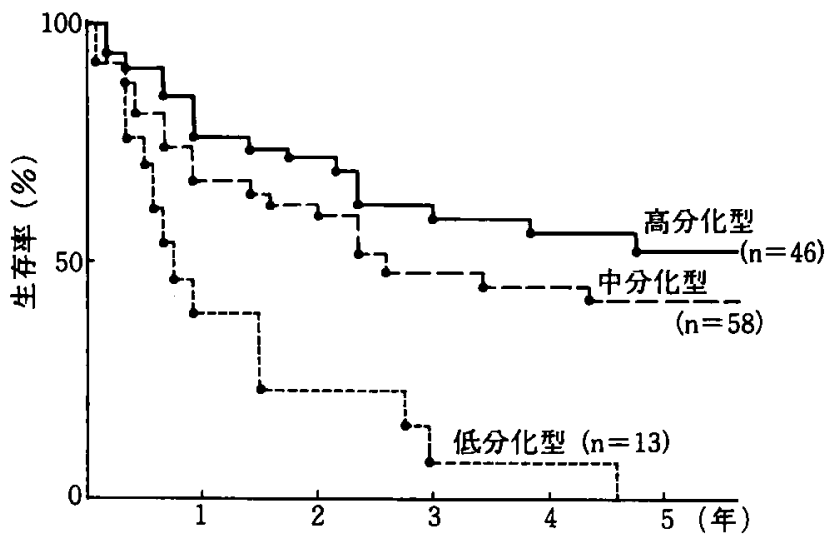

図 2 腺满の生存曲線



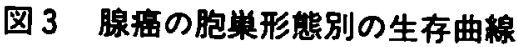

より中分化型の割合がやや高かったが低分化型は 1 例 る無かった. tubular type の24\%は低分化型であり， 逆に低分化型腺癌は tubular typeのみで占められた。

（4）分化度別生存曲線

扁平上皮癌の分化度別の生存曲線を, Kaplan-Meier 法で検討した（図 1)，5年生存率で比較すると，全体 では $39 \%$ であったが，高分化型44\%，中分化型38\%， 低分化型 $43 \%$ で分化度間の予後の差は殆ど認められな 
表 5 分化度と Stage の関係

扁平上皮蕰

\begin{tabular}{c|c|c|c|c|c}
\hline & Stage I & Stage II & Stage III & Stage IV & 合計 \\
\hline 高分化型 & 10 & 5 & 16 & 1 & 32 \\
中分化型 & 23 & 5 & 25 & 2 & 55 \\
低分化型 & 12 & 2 & 11 & 1 & 26 \\
\hline 合 計 & 45 & 12 & 52 & 4 & 113 \\
\hline
\end{tabular}

腺癌

\begin{tabular}{c|c|c|c|c|c}
\hline & Stage I & Stage II & Stage III & Stage IV & 合計 \\
\hline 高分化型 & 28 & 4 & 11 & 3 & 46 \\
中分化型 & 18 & 4 & 31 & 5 & 58 \\
低分化型 & 1 & 1 & 8 & 3 & 13 \\
\hline 合 計 & 47 & 9 & 50 & 11 & 117 \\
\hline Alveolar & 14 & 1 & 4 & 1 & 20 \\
Papillary & 21 & 5 & 25 & 5 & 56 \\
Tubular & 9 & 3 & 16 & 5 & 33 \\
\hline 合 計 & 44 & 9 & 45 & 11 & 109 \\
\hline
\end{tabular}

かった。

一方, 腺癌では全体の 5 年生存率は $40 \%$ であったが， 高分化型 $53 \%$ ，中分化型 $42 \%$ ，低分化型 $0 \%$ であり， 高分化型と低分化型（ $\mathrm{p}<0.01 ） ， お よ ひ ゙$ 分化型と低 分化型 $(p<0.05)$ との間に有意差を認めた（図 2$)$.

（5）腺癌の組織严型別生存曲線（图 3）

alveolar cell type の 5 年生存率は60\%で腺癌の中 で最も高く, tubular type の 5 年生存率は $22 \%$ と低 かった. papillary typeのそれは44\%で両者のほぼ中 間の値であった. alveolar cell type と tubular type と の間に有意差（p<0.05）を認めた。

alveolar cell type の中で高分化型と中分化型とに 分けて 5 年生存率を比較すると高分化型 $56 \%$ に対して 中分化型 $75 \%$, papillary type の中では高分化型49\%, 中分化型 $40 \%$ であった. tubular type は高分化型 $25 \%$, 中分化型 $33 \%$ に対して低分化型は $0 \%$ と低かった。

(6) Stage 分類と生存率

扁平上皮癌と腺癌を分化度別に Stage 分類すると (表 5 ), 扁平上皮癌では各々の Stage の占める割合は いずれすほ添同様であったが，腺癌では分化度が高い 生ど Stage I や II の早期例の割合が多かった．亜型分 類では alveolar cell type の70\%が Stage Iであった が, tubular type は64\%が Stage III, IV の進行例で あった。

（7）分化度別の根治度と生存率（表 6）

扁平上皮癌では分化度が低くなるほど絶対治撚切除 の割合が増えているが，非治痽切除の割合も低分化型
表 6 澼平上皮㾔の分化度と根治度の関係

\begin{tabular}{|c|c|c|c|c|}
\hline & 高分化型 & 中分化型 & 低分化型 & 合 計 \\
\hline 絶対治怎切除 & $11(34 \%)$ & $27(49 \%)$ & $13(50 \%)$ & $51(45 \%)$ \\
\hline 相対治密切除 & $10(32 \%)$ & $10(18 \%)$ & $3(12 \%)$ & $23(20 \%)$ \\
\hline 非治热切除 & $11(34 \%)$ & $18(33 \%)$ & $10(38 \%)$ & $39(35 \%)$ \\
\hline 合 計 & 32例 & 55例 & 26例 & $113(100 \%)$ \\
\hline 絶治 5 生率 & $61 \%$ & $63 \%$ & $84 \%$ & $70 \%$ \\
\hline 相治 5 生率 & $35 \%$ & $15 \%$ & $0 \%$ & $21 \%$ \\
\hline 2 生率 & $38 \%$ & $8 \%$ & $0 \%$ & $20 \%$ \\
\hline
\end{tabular}

表 7 腺癌の分化度と根治度の関係

\begin{tabular}{|c|c|c|c|c|}
\hline & 高分化型 & 中分化型 & 低分化型 & 合 計 \\
\hline 絶対治施切除 & $27(59 \%)$ & $18(30 \%)$ & $0(0 \%)$ & $45(38 \%)$ \\
\hline 相対治虚切除 & $7(15 \%)$ & $20(35 \%)$ & $2(15 \%)$ & $29(25 \%)$ \\
\hline 非治寉切除 & $12(26 \%)$ & $20(35 \%)$ & $11(85 \%)$ & $43(37 \%)$ \\
\hline 計 & 46例 & 58例 & 13例 & $117(100 \%)$ \\
\hline 5 生率 & $69 \%$ & $81 \%$ & $0 \%$ & $74 \%$ \\
\hline 5 生率 & $40 \%$ & $28 \%$ & $0 \%$ & $30 \%$ \\
\hline 2 生率 & $45 \%$ & $29 \%$ & $27 \%$ & $33 \%$ \\
\hline
\end{tabular}

表 8 発生部位と分化度

\begin{tabular}{l|r|c}
\hline & 肺門型 & 末梢型 \\
\hline 扁平上皮癌 & & \\
高分化型 & $15(47 \%)$ & $17(53 \%)$ \\
中分化型 & $28(51 \%)$ & $27(49 \%)$ \\
低分化型 & $8(31 \%)$ & $18(69 \%)$ \\
腺癌 & $2(4 \%)$ & $44(96 \%)$ \\
高分化型 & $5(9 \%)$ & $53(91 \%)$ \\
中分化型 & $3(23 \%)$ & $10(77 \%)$ \\
低分化型 & $0(0 \%)$ & $20(100 \%)$ \\
Alveolar cell type & $3(5 \%)$ & $53(95 \%)$ \\
Papillary type & $6(18 \%)$ & $27(82 \%)$ \\
Tubular type &
\end{tabular}

がやゃ多かった。絶対治瘜切除症例の 5 年生存率は低 分化型の方が良い結果がみられたが，相対的治病切除 症例の 5 年生存率や非治癁切除症例の 2 年生存率は高 分化型が良好であった。 即ち, 分化度と根治度との間 には一定の傾向は認めなかった。

腺癌では表 7 に示したように高分化型の59\%が絶対 治㾤切除可能であったのに対し，低分化型には 1 例る 無く, 85\%は非治痹切除に終わっている，絶対治痗切 除が可能であった症例の 5 年生存率で高分化型(69\%) より中分化型 (81\%) の方がやや高かった他は，分化 度が低くなるにつれて生存率が低下した。 
表 9 分化度と $\mathrm{T}$ およひ N因子との関係

\begin{tabular}{|c|c|c|c|c|c|c|}
\hline 扁平上皮癌 & $T_{1}$ & $T_{2}$ & $T_{3,4}$ & $N_{0}$ & $\mathrm{~N}_{1}$ & $\mathrm{~N}_{2,3}$ \\
\hline 高分化型 & $15 \%(5)$ & $41 \%(13)$ & $44 \%(14)$ & $44 \%$ (14) & $25 \%(8)$ & $31 \%(10)$ \\
\hline 中分化型 & $27 \%(15)$ & $35 \%(19)$ & $38 \%$ (21) & $53 \%$ (29) & $16 \%$ (9) & $31 \%(17)$ \\
\hline 低分化型 & $35 \%$ ( 9$)$ & $38 \%(10)$ & $27 \%(7)$ & $54 \%$ (14) & $12 \%(3)$ & $35 \%$ (9) \\
\hline 腺 & $T_{1}$ & $\mathrm{~T}_{2}$ & $T_{3.4}$ & $\mathrm{~N}_{0}$ & $\mathrm{~N}_{1}$ & $\mathrm{~N}_{2,3}$ \\
\hline 高分化型 & $39 \%(18)$ & $52 \%(24)$ & $9 \%(4)$ & $70 \%$ (32) & $9 \%(4)$ & $21 \%(10)$ \\
\hline 中分化型 & $36 \%(21)$ & $38 \%(22)$ & $26 \%$ (15) & $40 \%$ (23) & $12 \%(7)$ & $48 \%(28)$ \\
\hline 低分化型 & $8 \%(1)$ & $31 \%(4)$ & $61 \%(8)$ & $23 \%$ ( 3$)$ & $8 \%(1)$ & $69 \%$ (9) \\
\hline Alveolar & $50 \%(10)$ & $40 \%(8)$ & $10 \%(2)$ & $75 \%$ (15) & $5 \%(1)$ & $20 \%(4)$ \\
\hline Papillary & $34 \%(19)$ & $46 \% \quad(26)$ & $20 \%$ (11) & $46 \%(26)$ & $11 \%(6)$ & $43 \%(24)$ \\
\hline Tubular & $30 \%(10)$ & $33 \%$ (11) & $37 \%(12)$ & $40 \%$ (13) & $15 \%(5)$ & $45 \%$ (15) \\
\hline
\end{tabular}

（8）分化度および組織要型分類と畽場の占拠部位 (表 8 )

胸部 X 線写真, CT，気管支鏡，手術および病理所見 等より肺門型（区域支までに発生したもの）と末梢型 （亜区域支より末梢に発生したもの）の 2 つに分類し た。扁平上皮癌では高分化型, 中分化型の $50 \%$ 近くが 肺門型で占められたが，低分化型では肺門型の割合が 31\%と低かった。一方腺癌では高分化型および中分化 型の大部分が末梢型で肺門型は少なかったが，低分化 型では肺門型が23\%を占めた。これを組織亜型分類で みると, alveolar cell type では全て末梢型であるのに 対して papillary type で $5 \%$, tubular type では18\% が肺門型であった。

（9）分化度と $\mathrm{T}$ およU $\mathrm{N}$ 因子の関係（表 9）

扁平上皮癌では $\mathrm{N}$ 因子の大小と分化度とは殆ど関 係なかったが，T因子に関しては分化度が高くなる玨 ぞT因子が増す傾向が認められた。一方, 腺癌では分 化度が低くなるはど T 因子や N 因子が増える傾向が あった。腺癌の組織亜型分類でも alveolar cell type, papillary type, tubular type の順で $\mathrm{T}$ 因子ゃ $\mathrm{N}$ 因子 が增す傾向が認められた。

\section{考 察}

肺癌の手術症例の予後は当然のことながら組織型, 病期, 手術の根治度の 3 つの要素によって大きく異な る2、。しかしこれらの要素が同一であっても現実には 個々の症例の生存率にはかなりのばらつきが認めら れ，予測された予後と異なる症例も少なくない，その 原因の一つとして肺癌は他臓器の癌と比較して発生母 地を異にする多様な組織が混在し, 病理組織像も多彩 である事があげられている3)。これまでも各組織型の 中でいろいろな亜型分類が試みられており，それらと
予後との関係を述べた報告る見らけられる45). 特に腺 癌では光顕的, 電顕的にさらに細かく分類した報告677) ああるが未だ広く支持されるには至っていないよらに 思われる. 組織型以外の分類方法としては血管浸潤の 程度 ${ }^{8) \sim 10)}$ やリンパ管侵襲11)の有無, 腫掦中心の線維化 巣の硬さ等と予後を比較した報告6)12) あるが，今回 の我々の検討では組織学的悪性度を表現するとされる 分化度について分類した。

扁平上皮癌の生存曲線は図1のごとく，各分化度間 の生存率に差を認めず, 各分化度間での根治度と予後 においても差を認めなかった(表 6 ).ささらに Stage I, II の絶対治瘦切除の 5 年生存率や, Stage III, IV の非 治撚切除の 2 年生存率についても検討したが，ともに 差を認めることはできなかった。このことは扁平上皮 癌の予後は腫煬の大きさやリンパ節転移の有無などの 病巣の広がり, 手術の根治度に大きく影響され, 分化 度が予後を左右するほどの関係はないと言える ${ }^{13)}$ ．高 分化の扁平上皮癌汪と腫場径が大きく肺門側に発生し

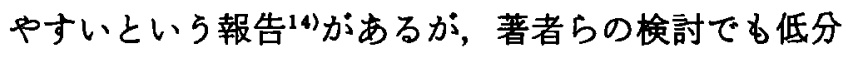
化型の肺門型の割合 $31 \%$ に対し，中分化型 $51 \%$ ，高分 化型 $47 \%$ であり，低分化型に比較して肺門側に発生す る率が少し高かった(表 8)。また表 9 に示したように $\mathrm{T}$ 因子では $\mathrm{T}_{1}$ は分化度が低い:ど， $\mathrm{T}_{3,4}$ は分化度が高 いはどその頻度を增していたことからも椥える。この ような傾向が認められながらも高分化型の生存率が低 くないのは，扁平上皮癌では実際は分化度が高くなる ほど予後の良い性質を有していながら，肺門側に発生 し易いためにその性質が帳消しにされている可能性が 考えられる.N因子は分化度間に差が無く，分化度が 低くなるほどN 因子が增す傾向 ${ }^{15)}$ は認められなかっ た。 
腺癌では高分化型の 5 年生存率 $53 \%$, 中分化型 $42 \%$ に対し低分化型では $0 \%$ と悪かった。腺癌では高分化 型の予後が良好とする報告(46)1516) もあれば分化度と 生存率に差がないとする報告17) 見られるが，われわ れの検討では分化度が低くなる汪ど予後が悪かった。

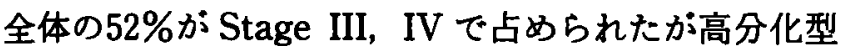
$30 \%$ ，中分化型 $62 \%$ ，低分化型 $85 \%$ のよに，分化度 の低いものほど進行例が多い傾向を認めた。そ原因 としては分化度が低くなるほど肺門側に発生しやすい ことあ一因であろらが(表 8 )，表 9 に示したように低 分化腺癌ほど $T_{3.4}$ が多く，增殖の速度が速いためと考 えられる。また，分化度が低いはど $\mathrm{N}_{0}$ 症例が少なく $\mathrm{N}_{2,3}$ 症例が増加し、リンパ節転移が起こり易い傾向が 推察された。これらのことは高分化型ほど末梢型の占 める割合が高くなり，増殖の速度も遅く，畽場径の小 さいものが多く ${ }^{14)}$, リンハ節転移の頻度も少なく，その 結果早期発見される率が高くなって予後も良くなると 換言できよ5．たたし，分化度の判定は大勢を占める 分化の程度でもってなされるため，低分化な部分が混 在していながら高分化型や中分化型と判定されたよう な症例が含まれ，予後を悪くしていることも考古られ る.

腺癌の胞巣形態別分類では図 3 K示したように alveovar cell type の予後が最も良好であった。これは その75\%が $\mathrm{N}_{0}, 50 \% か ゙ ~ T_{1} て ゙$, 全て末梢型のため(表 8， 9) と思われ，末梢限局型の alveolar cell type の予後 は良好と言える ${ }^{16) 18)}$. 高分化型の alveolar cell type の 5 年生存率 $56 \%$ に対して，中分化型のそれは $75 \%$ とむ しろ高かったことから，高分化型腺癌の予後の良いの は alveolar cell typeの含まれる割合が多い結果と考 えられる。

M 因子と分化度については Stage IV $\left(M_{1}\right)$ の占め る割合を表 5 より求めると, $\mathrm{M}_{1}$ 症例数はいずれも少な いが，扁平上皮癌ではどの分化度です $3 \sim 4 \%$ 程度で あるのに対し，腺癌では高分化型で $7 \%$ ，中分化型 $9 \%$ ，低分化型23\%の上うに分化度が低くなるほど $\mathrm{M}_{1}$ の頻度が増えた。これらの症例の大部分は $\mathrm{PM}$ 因 子のために Stage IV となったるのである.

平均年龄と分化度の比較では，分化度が低くなる伍 と平均年齢も低下するとした報告 ${ }^{199}$ あるが，我々の 検討（表 3）では，症例数の少ない低分化型腺癌の平 均年龄がやや低かった他はいずれも61から62歳で特に 差は認めなかった。

性差と分化度については，扁平上皮癌では女性の低
分化型が，腺癌では男性の低分化型が多いとする報 告19がある．われわれの症例でも女性の扁平上皮癌症 例数は少ないものの, その割合は分化度が低くなるに つれて 3\%，6\%，8\%と僅かながら増加した。 また 高分化腺癌では男性が52\%を占めるに対して低分化腺 癌では $85 \%$ も占めていた（表 2 ）。

\section{まとめ}

当科で手術された扁平上皮癌113例および腺癌117例 を分化度別に分類して予後を検討した結果，以下の上 らな結論を得た。

1. 扁平上皮癌では分化度と予後の間には一定の傾 向は認められなかった。

2. 腺癌では低分化型の予後が悪く, 亚型分類では alveolar cell type の予後が良好であった。

3. 扁平上皮癌では高分化のすのほど, 腺癌では低分 化のものほど肺門側に発生しゃすい傾向が認められ た。

4. 扁平上皮癌では根治度と分化度との間に殆ど関 係がみられなかったが，腺癌では分化度の低いむの汪 ぞ絶対治瘾切除の割合が減少し, 非治瘱切除の割合が 増加した。

5. 腺癌では低分化のものほど TNM の各因子の数 が増え，予後が不良であった。

6. 平均年齢と分化度との間に差は認められなかっ た.

7. 扁平上皮癌では女性の低分化型が, 腺癌では男性 の低分化型が多い傾向にあった。

\section{文献}

1）日本肺癌学会編：臨床·病理, 肺癌取扱い規約, 改 訂第 3 版，金原出版，1982

2）吉村克俊，山下延男：全国集計よりみた肺癌の治 療と予後を左右する因子，肺癌 22：117-125, 1982

3）下里幸雄：肺癌，その組織発生，分化，予後因子に ついて，日病会誌 $72: 29-57,1983$

4）山口 豊, 斉藤幸雄, 岩井直路他：肺癌の組織型と 手術成績，外科治療 $55: 28-34,1986$

5）宮本 宏, 伊藤正美, 高岡和夫他：肺腺癌の組織像 と予後との関係, 肺癌 $25: 1023-1029,1985$

6）児玉哲郎：肺腺癌の細胞分化および予後因子. 肺 癌 $25: 387-392,1985$

7) Kimula Y : A histochemical and ultrastructural study of adenocarcinoma of the lung. Am J surg Pathol 2 : 253-264, 1978 


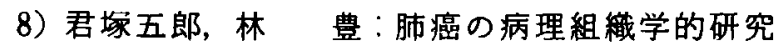
一ことに悪性度の関連について一, 肺癌 $19: 167$ $-175,1979$

9）建石竜平，土井 修，児玉 憲他：肺腺癌の組織要 型と術後予後一とくに乳頭状腺癌と印環細胞腺癌 について一，肺癌 $25: 381-385,1985$

10）栗田 啓：肺癌における組織学的予後決定因子の 検討, 肺癌 $28: 37-47,1988$

11) Higgins GA, Beebe GW: Bronchogenic carcinoma-Factors in survival. Arch Surg $94: 539$ $-549,1967$

12）橋本武志, 下里幸雄, 児玉哲郎他：肺の末梢に発生 した小型腺癌, 大細胞癌の臨床病理学的研究, 特に 腫疸中心部線維化巣の形態と予後との関連につい て, 肺癌 $18: 381-389,1978$

13）児玉哲郎：病理学的にみた肺癌の多様性と予後, 癌と化療 $12: 45-53,1985$

14）森田豊彦：肺癌剖検例からみた男女肺癌の異同 一腺癌と扁平上皮癌の分化度一(後編：発生部位,
腫瘍の大きさ及び転移)，肺癌 $25 ： 965-976$, 1985

15) Chung CK, Zaino R, Stryker JA, et al : Carcinoma of the lung : Evaluation of histological grade and factors influencing prognosis. Ann Thor Surg 33: 599-604, 1982

16）服部正次, 池上晴通, 建石竜平他：肺腺癌の組織亜 型分類別および分化度別にみた術後成績, 肺癌 19 : $361-370,1979$

17）深井志摩夫, 石原佰夫, 山崎史朗他：肺腺癌切除後 の予後に関与する因子について，肺癌 $23 ： 573$ $-581,1983$

18) Hukill PB, Stern H : Adenocarcinoma of the lung-Histological factors affecting prognosis. Cancer $15: 504-514,1962$

19）森田豊彦：肺癌剖検例からみた男女肺癌の異同 一腺癌と扁平上皮癌の分化度一(前編：分化度. 年 龄及び啰煙)，肺癌 $25: 625-634,1985$

\title{
DIFFERENTIATION AND PROGNOSIS OF LUNG CANCER
}

\author{
Masaki MUKAI, Fumito KURANISHI, Shinkichiro YOSHIOKA, Tsuneo OKUMICHI, \\ Masayuki NISHIKI, Kiyohiko DOHI and Toshihiro KOBUKE* \\ Second Department of Surgery, Hiroshima University School of Medicine \\ *Second Department of Pathology, Hiroshima University School of Medicine
}

From 1972 to 1987, 274 patients with lung cancer were operated on in our institute. A retrospective study was done on 113 cases of squamous cell carcinoma and 117 cases of adenocarcinoma which could be classified histologically by degree of differentiation.

Five-year survival rates in squamous cell carcinomas were $44 \%$ in well differentiated type, $38 \%$ in moderately differentiated type, and $43 \%$ in poorly differentiated type, in that no particular difference in prognosis was noted. While the rates in adenocarcinomas were $53 \%, 42 \%$, and $0 \%$, respectively. These figures might mean that a decrease in differentiation worsened the prognosis. The prognosis of the alveolar cell type was as good as $60 \%$, but that tubular adenocarcinoma was as poor as $22 \%$.

In squamous cell carcinomas, the better the degree of differentiation, the higher was a tendency to develop into the central type, but no correlation was noted between the degree of differentiation and prognosis. In adenocarcinomas, an increase in the degree of differentiation decreased the tendency to develop into the central type, the $T$ number, and the rate of metastasis of the lymph nodes, but increased the number of curative operations. Consequently, early detection is an important factor for favorable prognosis. 